\title{
ANATOMY OF SUSTAINABLE TOURISM DEVELOPMENT: A CASE STUDY OF THE CITY OF SPLIT
}

\author{
Lidija Petrić, \\ Biljana Crnjak-Karanović \\ University of Split, Faculty of Economics, \\ Split, Croatia
}

Correspondence:

Lidija Petrić

e-mail:

lipe@efst.hr

\begin{abstract}
:
By accepting the fact that there are many different approaches to sustainable development, this paper aims to investigate, using a particular case study, whether tourism development model of the city of Split, Croatia, a well-known tourism destination, is based on the principles of sustainability, thus proving its orientation to quality assurance.

The authors have analyzed this model from all three aspects of sustainability, i.e. economic, environmental and social. For the purpose of a deeper investigation of this matter, desk research has been conducted consulting a substantial amount of sources. The paper is structured as follows: after a brief overview of the concept of sustainable tourism development from the three main sustainable development aspects, the question of co-habitation of sustainability, quality and competitiveness of a tourism destination is raised. The main part of the study attempts to draw the three main aspects of sustainability together by blending the theoretical issues with the practical experience from the case study. Alongside with highlighting the basic developmental issues, proposals of tourism management mechanisms in the city of Split are offered with the aim of making it more sustainable and hence, fostering its long-run quality and attractiveness.
\end{abstract}

\section{Keywords:}

destination, sustainability, quality, city of Split.

\section{INTRODUCTION 1}

The issue of sustainable development has been well researched in extant literature and attracted considerable debate and analysis from virtually all academic standpoints (Petrić, 2012). Although numerous papers and books have been written on this topic, from the so called Bruntland's report in 1987 (World Commission on Environment and Development) up to the most recent book, titled The Age of Sustainable Development (2015), written by a well-known American scholar, professor Jeffrey Sachs, it cannot be said that there is a universally acceptable definition of this concept. However, most definitions highlight three major pillars of the sustainability concept, i.e., economic, social and environmental (Munasinghe, 2003, as cited in Petrić, 2012).

1 Some parts of this research have been based on a book chapter: Petrić, L. (2012), Croatian Tourism Development Model - Anatomy of an Un/sustainability. In Ghenai, C. (Ed). Sustainable Development - Policy and Urban Development - Tourism- Life Science-Management-Environment / Book 3. (pp. 119-147). In Tech Open Access Rijeka. 
Along with the evolution of sustainable development discourse, concerns about the environmental and social impacts of tourism have escalated in recent years due to the ever-growing trend of tourism demand, with the projection of more than 1.8 billion arrivals worldwide by 2030 (United Nations World Tourism Organization, 2016). What additionally worsens this situation is an uneven distribution of tourist flows in terms of their dominant regional concentration (predominantly Europe) and high seasonal concentration of demand (Petrić, 2012). Such concept of mass tourism development poses intense pressure on the overall capacity of destinations to cope with tourists and their numerous activities within a relatively short period of time. This situation gradually brings destinations to the supply quality degradation, and consequently, diminishes both residents' and visitors' satisfaction, which is well explained by the Butler's theory of a destination's life cycle and Doxey's index of irritation (Claiborne 2010, as cited in: Petrić and Pivčević, 2016).

Any destination that tends to avoid the loss of attractiveness and competitive position in the market in the long run has to opt for sustainable development in all three aspects of sustainability. Hence, in order to achieve economic sustainability which presumes growth, efficiency and stability (Munasinghe, 2003, as cited in Petrić, 2012), some preconditions are to be fulfilled. Firstly, destination's authorities have to take care of the appropriate structure, quality and number of accommodation capacities so as to ensure optimal financial results for all stakeholders. Furthermore, special measures should be introduced for the purpose of distributing demand evenly in space and time (through subsidies and tax exemptions on the supply side and/or different marketing techniques on the demand side). Local authorities together with the local Destination Management Organization (DMO) should invest considerable effort, using a set of economic tools, to attract investors to a destination, particularly those who can guarantee high quality of services without endangering its resources in the long run.

Environmental sustainability is achieved when environment is preserved and properly protected and pollution reduced to a minimum. It may be realized by a number of measures. However, most of them come out of a comprehensive/integral planning policy created with respect to a destination's carrying capacities. Also, environmental sustainability strongly depends on whether the destination and all its stakeholders have implemented different environmental management measures such as "reduce-reuse-recycle measures", eco taxes, environmental management charge, group size limitations, eco certification (Petrić, 2011).
Social sustainability based on competent local government and empowered local community is achieved by enhancing education, strengthening the participation of the local community in the planning processes, by creating networks, public-private partnerships and other types of cooperation and by enhancing socially responsible behavior in the community (Petrić, 2012).

Based on the above-given theoretical overview, this paper tends to further investigate, through an analysis of the specific case study, whether tourism development model in the city of Split, Croatia, a well-known tourism destination, is oriented towards sustainability and hence, quality assurance. The main part of the study attempts to draw three main aspects of sustainability together by blending the theoretical issues with the practical experience from the case study. After highlighting the basic developmental issues, some tourism management mechanisms are proposed in the city of Split in order to make it more sustainable and to foster its attractiveness, quality and competitiveness in the long run.

\section{DISCUSSION}

Sustainability - attractiveness - quality - satisfaction - tourism destination competitiveness; is there co-habitation?

The issue of tourism sustainability is usually associated with the concept of quality. It is widely accepted that destination attributes determine the perceived quality of a destination's supply, and that perceived quality affects visitors' satisfaction (Žabkar et al., 2010). Satisfaction is considered to be the central concept in tourism (Chen and Tsai, 2007; Prayag, 2009). However, the findings regarding the quality components that (co) shape the overall quality perceptions, and their relative importance differ, since "relevant attributes are destination-specific and cannot be generalized across destinations" (Žabkar et al., 2010, p. 543). What can be generalized are the consequences of satisfaction, i.e. satisfaction influences the choice of a destination, the consumption of products and services and the decision to return. As competition between destinations intensifies, the attractiveness of a destination becomes crucial. Mayo and Jarvis (1980; as cited in Vangesayi, 2003, p. 638) define attractiveness as "the perceived ability of the destination to deliver individual benefits." This ability is enhanced by the attributes of a destination (Vangesayi, 2003), since these attributes help people to evaluate the attractiveness of a destination, and make relevant choices (i.e. choose one destination over another). Tourism destination will assume a successful position in the tourism market depending on 
how tourism attractions develop value for tourists, and how well destination resources are managed (Gomezelj and Mihalic, 2008; Heeley, 2015).

Considering everything written so far, it can be concluded that maintaining a high level of quality is important for tourism destinations competitiveness. To that end, a carefully designed and well executed program of destination management (DM) becomes vital, as it can contribute to destination's sustainability. Go and Govers (2000) have proved, by examining quality management performance in seven European destinations that, despite the whole range of common policies and related instruments, each of them has formulated diverging strategies to manage their quality, thus supporting the claim that destination management is destination specific. A tourism destination is perceived by tourists as a single entity. In fact, it comprises several stakeholder groups: host population, tourists, public sector and government, tour operators and tourism enterprises (Buhalis, 2000). The interest and priorities of various stakeholders do not always coincide, which is why destinations are considered the most difficult entities to manage (Dmitrovic et al., 2009; Petrić, 2011). The task of destination management (and marketing) is often entrusted to a Destination Management Organization (DMO). It is imperative for a DMO to ensure that benefits of tourism activity are shared fairly between all stakeholders and that sustainable practices safeguard the regeneration of resources utilized in tourism production. As explained by Buhalis (2000), DMO should act as a tool and facilitator to achieve a range of strategic objectives such as maximizing visitors' satisfaction and profitability of local enterprises, enhancing the long-term prosperity of the local population, and optimizing available resources through destination's sustainable development.

To conclude, co-habitation between sustainability-attractiveness-perceived quality of destination supply-satisfaction-competitiveness does exist. Destination sustainability and destination competitiveness are like two sides of the same coin. One side of the coin (i.e. sustainability) reflects the supply-side view, while the other one (i.e. competitiveness) reflects the demand-side view.

In the following chapters, supply-side view of the present state of the art of tourism development in the city of Split is briefly analyzed for the purpose of drawing attention to the fact that it is far from being sustainable, although as an emerging destination, it still experiences an ever-growing demand. However, as the problems continuously grow, the question imposes as to how long the city of Split will fulfill tourists' expectations and what actions should be taken to help it become more sustainable and to retain or even enhance its competitive position.

\section{A case study: Tourism development in Split, Croatia}

According to the 2011 census (Croatian Bureau of Statistics, 2011), the city of Split had 178,102 inhabitants, with a wider urban area reaching over 300,000 inhabitants. As an intraregional transport hub and popular tourism destination, the city is a link to numerous Adriatic islands and the Apennine peninsula. It is one of the oldest cities in the area. While traditionally considered just over 1,700 years old, counting from the construction of Diocletian's Palace in 305 AD, the city was in fact founded as the Greek colony of Aspálathos in the 4th century BC, about 2,400 years ago. The present city of Split has developed into a modern town keeping traces from all periods and incorporating them into a harmonic whole. In 1979, its historic core with the Diocletian's palace was declared a World Heritage Site on account of its well-preserved architecture from all periods, but also because of the fact that it is still a living organism with all urban functions. Although Split was the administrative and economic center of the middle Dalmatia, its development has been threatened by a devastating process of deindustrialization of suburban areas after 1990s, which took the city on the crossroads without a clear idea on where to go to. Due to the lack of development vision, tourism has gradually become the most dominant, if not the only economic activity in the city (Petrić and Pivčević, 2016).

\section{Is tourism development in Split sustainable \\ in the economic sense of the word?}

To answer the above question, it is necessary to reassess the development model of Split tourism. It is noteworthy that before 1990s up to the middle of the 2000s, the city of Split was a transit destination for the visitors travelling to the middle Dalmatian islands. Due to the proliferation of the real estate market demand for the properties in Split and individual efforts of the industrious local entrepreneurs, tourism demand has gradually started to grow, from approximately 80,000 arrivals and 110,000 overnights at the end of the 1990 s up to 458,465 arrivals in 2015 (growth of 16\% compared to 2014) and $1,353,957$ overnights (growth of $22 \%$ ), according to the Split Tourist Board. Unfortunately, these numbers are still mostly concentrated on the period between June and September with more than $85 \%$ of overnights and $80 \%$ of arrivals realized. Such a tremendous concentration of visitors within a short period of time brings into focus the 
problem of spatial oversaturation i.e. carrying capacities being overpassed. Apart from the gentrification process, a rapid "tourismification" has been changing the usage of the old buildings in the historic core turning them into seasonal accommodation facilities (Mikulić and Petrić, 2013, as cited in Petrić and Pivčević, 2016). It is an amazingly rapid process. According to the Tourism Board Data for the year 2014, Split recorded in total 14.188 tourist beds, which is $73 \%$ more compared to 2012. In 2015, there were approximately 17,047 beds available, indicating further growth of $20 \%$ within just one year. Out of 14,188 beds registered in Split in 2014, only 2,908 were hotel beds (or 20\%), most of them (over $80 \%$ ) being 4 and 5 star hotels, while the rest of $80 \%$ or 11,280 was in supplementary capacities, dominantly private households and apartments which, despite their growing quality are not city's entrepreneurial potential but more a social phenomenon. Also, it can be observed that apart from the Radisson Blu hotel chain, Split hasn't attracted any other international chain. The reasons for that lie in rather short tourist season, and lack of both entertainments in the post seasonal period and direct connections with European capitals during the year. Because of the poor statistics, the general data on Croatian hotel sector performance may be used to indicate poor efficiency of the hotels in Split. Hence, the Average Daily Rate of 99 EUR per room/day in 2013 is lower in Croatia than in other rival tourism country, such as in France, Italy, Greece and Turkey (with 167.4; 126.8; 101 and 100.5 Euro's per day, respectively). As regards the Revenue per available room (RevPar) indicator for 2013, the situation is quite the same: it is lower in Croatia (45.2) than in other competitor countries (112.7 in France, 77.1 in Italy, 57.8 in Greece and 63.3 in Turkey) (Galičić, 2015).

It is worth mentioning an ever worsening problem of the infrastructure which is not sufficiently developed to follow the rapid growth of demand and needs of other users. There is a constant lack of parking places and other communal and traffic infrastructural facilities that have been planned for incomparably lower number of users.

The short analysis of the economic performance of the Split tourism development model has shown that the main requirements of sustainability, i.e. growth, efficiency and stability, have not been fulfilled in a satisfactory manner. Split tourism is unfortunately developing with hardly any strategy. Measures have been put into operation with no respect to the wider context of development, and the consequences of bad decisions are usually not penalized.
Environmental sustainability of the Split tourism:

The truth behind the numbers

As already highlighted, the city of Split is suffering from an uneven time and spatial distribution of demand leading to the high concentration of accommodation facilities in the old and fragile historic core. This can be proved by the so called tourism functionality index (TFI), which represents the ratio between the highest number of tourists in the peak season and the number of permanent population and is measured by the number of beds per 100 inhabitants. With regard to the city of Split as a whole, TFI indicates a rather low coefficient, only 7.8 beds per 100 inhabitants. However, when calculated for the city historic core, it grows up to 94.35 in 2014 (related to 60.85 in 2012), which is very high with the further growing tendency. To add to tourism oversaturation argument, one has to bear in mind that Split also hosts on average 300,000 cruise tourists per year, coming mostly from May to October, a huge number of daily visitors from the County (which hosts over 12 mil tourists per year) and elsewhere and other people in transit (over 7 mil passengers on a yearly basis), not to forget the citizens of Split and its gravitating area. Such a concentration of people within a short period of season creates various pollution problems and the consequent change or loss of biodiversity. Damages to cultural heritage occur on a daily basis, including the cultural identity (or so called "genius loci") loss.

Although the ecological awareness among tourist entrepreneurs has an ever-rising trend, implementation of the concept of environmental management is still a rare case. The exceptions are the hotels operating within international chains whose ecologically oriented operation is the basic element of their competitive strategy (such as the Radisson Blu hotel in Split which is the first city hotel possessing the Green Key international eco certificate). Recently, a few small city hotels have implemented measures to rationalize energy consumption due to the active national subsidizing program. Noteworthy is that although Split has 5 beaches and 2 marinas with the EU Blue Flag certificate, this is not satisfying given that it possesses more than $25 \mathrm{~km}$ of beaches. As for other environmental management instruments, they are not used at all to our best knowledge. Although Split has spatial plans and a number of written strategic documents, monitoring of their implementation is rarely done consequently leading to voluntarism in the use of its resources. One of the worst examples of such voluntarism is urban chaos on the very famous city bathing area named Žnjan, which hosts, on a relatively narrow maritime (state protected) line, 26 improvised café bars, most of them doing business illegally. 
Though positive changes have been recorded in Croatia as a whole, especially after its accession to the European Union, there is still much to be done in terms of building social capital (Petrić, 2012). Within this concept public governance efficiency enhancement and local community empowerment are the two basic issues to be considered. The local government of the city of Split, no matter which political option it belongs to, doesn't actively manage the tourism development processes, leaving them completely to the arbitrariness of local entrepreneurs. Poorly managed "cultural tourism", to a great deal "consumed" by daily visitors, dominantly cruise ship visitors, has additionally deteriorated the quality of life in the historic core of the city, transforming it into a stage for non-authentic, tourist performances. With the recent rise of party tourism, it has become evident that the City government has no clear vision on how to position the city on the tourism market and what consequences it will experience in the near future due to such unplanned tourism development. At the same time, in the absence of other economic activities, thousands of small entrepreneurs and room renters get involved in tourism business (often with no previous knowledge and education in tourism). Many of them don't even consider the possibility of doing tourism on a whole-year basis and are most often not even interested in participating in its management and planning. The findings of the pilot research study conducted on a sample of 132 Split community members from December 26, 2015 until January 26, 2016, have mostly confirmed the above-given assumptions proving that unsustainable or "tourism vs. community" development model is being in place in Split (Petrić and Pivčević, 2016). In addition, local entrepreneurs prefer engagement in national associations rather than in local/regional networks. Obviously, there is no systematic approach to empowerment of the Split community to actively contribute to sustainable tourism development.

Further analysis of the local accommodation facilities' web sites shows that the concept of socially responsible behavior has been rarely implemented in their business strategy. The exception is the EU funded project "Responsible behavior cleans the world", launched by five city hotels together with the local non- government organization and the University of Split with the aim of founding a small soap recycling centre employing the disabled people. It should be noted that although public-private partnerships may have a variety of forms, one can find rare cases of it in Split, mostly in the area of new events creation, promotion and stakeholders education through the tourist board.
The city of Split will undoubtedly remain the mass tourism destination in the future. However, the dilemma reimains as to what kind of mass tourism it will turn into, undifferentiated and seasonal, as it is now or the one that has more modest growth in the number of tourists but is focused on their seasonal (and spatial) redistribution. If this option is chosen, Split has to create a spectrum of both direct and supplementary tourism services that can satisfy different kinds of guests. However, due to its status of the UNESCOs city, Split should put most of its efforts into cultural tourism development, which may be a trigger for more intense cultural and creative industries development. Also, it is essential that it develops a wider spectrum of economic activities which is important not only for creating more diversified tourist supply but it also helps in reducing the local economy overreliance on tourism. Local authorities together with the local DMO should put more efforts into rising the awareness of the positive and negative effects of tourism among the local population. They should also support promotion and implementation of a planned solution, which ensures that the unique destination identity is maintained. The level of control over the behavior of all relevant stakeholders should also be raised. Apart from hard management tools/instruments, the soft ones, such as education, partnership, networks and other kinds of cooperation should also be implemented for the purpose of rising up the management efficiency of the local tourism system as a whole. Also, by introducing eco certificates, codes of conduct, Carrying Capacity Assessment and other tools and instruments, the principles of responsible behavior should be promoted and implemented more intensely (Petrić, 2012). This list is not exhaustive and indicates a range of principles that underpin the strategic and integrated planning for tourism areas.

\section{CONCLUSION}

The nature of tourism is obviously ambivalent. On the one hand, it might act as a catalyst for wider socioeconomic development or regeneration of a tourism destination, while on the other one, the growth of tourism generates different environmental costs usually accompanied by a variety of economic, social, cultural and political consequences. For the purpose of avoiding or at least diminishing these costs and achieving sustainability, destination should employ the appropriate management 
techniques and tools, including the use of integral/comprehensive planning as the most important one.

The case study of the tourism development model of the city of Split has shown that sustainability has not been achieved in any of the observed areas. Because of this, its long-term attractiveness and competitiveness is endangered, hence urging for immediate actions.

\section{REFERENCES:}

Buhalis, D. (2000). Marketing the competitive destination of the future. Tourism Management, 21(1), 97116. doi:10.1016/S0261-5177(99)00095-3.

Chen, C. F., \& Tsai, D. (2007). How destination image and evaluative factors affect behavioral intentions? Tourism Management, 28(4), 1115-1122. doi:10.1016/j.tourman.2006.07.007.

Croatian Bureau of Statistics (2016). Census of Population, Households and Dwellings 2011. Statistical report 1583. Zagreb: Croatian Bureau of Statistics.

Dmitrović, T., et al. (2009). Conceptualizing tourist satisfaction at the destination level. International Journal of Culture, Tourism and Hospitality Research, 3 (2), 116-126. doi:10.1108/17506180910962122.

Galičić, V. (2015). Tourism in Croatia: Truths and Misconceptions. Informatologia, 48(1-2), 78-94.

Go, F. M., Govers, R. (2000). Integrated quality management for turist destinations: a European perspective on achieving competitiveness. Tourism Management, 21(1), 79-88. doi:10.1016/S02615177(99)00098-9.

Gomzelj, D. O., \& Mihalic, T. (2008). Destination competitiveness - applying different models, the case of Slovenia. Tourism Management, 29(2), 294-307. doi:10.1016/j.tourman.2007.03.009.

Heely, J. (2010). Urban destinations marketing in contemporary Europe - what does „good“ look like? International Journal of Tourism Cities, 1(1), 3649. doi:10.1108/IJTC-08-2014-0003.
Petrić, L. (2011). Upravljanje turističkom destinacijomnačela i praksa. Split: Faculty of Economics, University of Split. In Croatian.

Petrić, L. (2012). Croatian Tourism Development Model - Anatomy of an Un/sustainability. In Ghenai, C. (Ed). Sustainable Development - Policy and Urban Development - Tourism- Life Science - Management-Environment / Book 3. (pp. 119-147). Rijeka. In Tech Open Access. Retrieved August 2, 2016, from http://www.intechopen.com/books/ sustainable-development-policy-and-urban-development-tourism-life-science-managementand-environment. doi:10.5772/2426

Petrić, L., \& Pivčević, S. (2016). Community based tourism development - insights from Split, Croatia. In Tourism \& Hospitality Industry 2016, 28-29 April, 2016. (pp. 294-307). Opatija: Faculty of Tourism and Hospitality Management.

Prayag, G. (2009). Tourists' evaluations of destination image, satisfaction and future behavioral intentions: The case of Mauritius. Journal of Travel and Tourism Marketing, 26(8), 836-853. doi:10.1080/10548400903358729.

Sachs, J. (2015). The Age of Sustainable Development. New York: Columbia University Press.

United Nations World Tourism Organization. (2016). Tourism highlights. Madrid: UNWTO. doi:10.18111/9789284418145.

Vengesay, S. (2003). A Conceptual model of tourism destination competitiveness and attractiveness. ANZMAC 2003 Conference Proceedings, 1-3 December, 2016 (pp. 637-647). Adelaide: University of South Australia.

World Commission on Environment and Development, (1987). Our Common Future. Retrieved June 12, 2016, from http://www.un-documents. net/wced-ocf.htm.

Žabkar,V., Makovec Brencic, M., \& Dmitrovič, T. (2010). Modelling perceived quality, visitor satisfaction and behavioural intentions at the destination level. Tourism management, 31(4), 537-546. doi:10.1016/j.tourman.2009.06.005. 